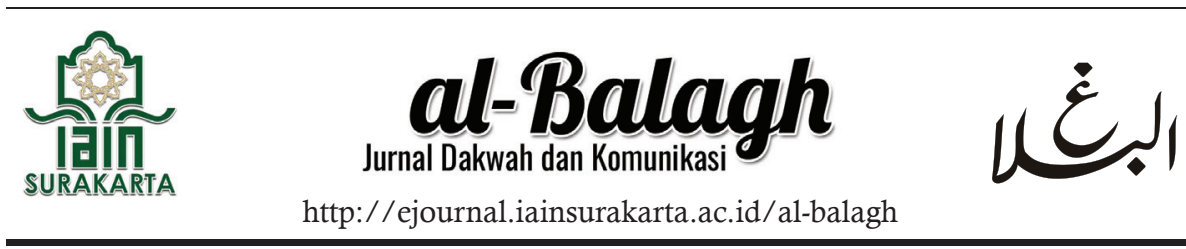

\title{
ANALYSIS OF CONSENSUAL HALLUCINATION PHENOMENA IN NETSPEAK, NETLINGO PRACTICE, AND MILLENNIAL GENERATION NETIQUETTE
}

\author{
Wahyuni Choiriyati \\ Universitas Pertamina \\ Dinda Rakhma Fitriani \\ Universitas Gunadarma

\section{Leo Susanto} \\ Kementerian Hukum dan Hak Asasi Manusia
}

\section{Keywords:}

Textual

Communication;

Netspeak; Netlingo;

Netiket; Consensual

Hallucinations

\begin{abstract}
This phenomenological research aims to uncover textual digital communication practices involving netspeak and netlingo also forms of millennial consensual hallucinations on social media. The novelty of this research is the millennial generation category, which has new netiquette as a consensus. Research obtained through interviews with informants concluded the practice of textual communication. The first practice is netlingo, which produces a speech-language which is then turned into text, such as expressions of surprise that are modified in written form. The form of netspeak concluded from this research is capital letters to express communication emotions. Textual communication used on social media such as Instagram and Whatsapp cannot make a sound but has become a mass convention for social media users. This research puts the concept of netspeak and netlingo that can encourage consensual hallucinations. These hallucinations are in the form of the assumption that social media is a free and equal place, so there are no restrictions like the real world. Hallucinations for millennials are assumed to be equality in communication
\end{abstract}

Correspondence:

e-mail: wahyuni.choiriyati@universitaspertamina.ac.id dinda_rf@staff.gunadarma.ac.id leosusanto93@gmail.com 


\begin{tabular}{l}
\hline \\
\hline Kata kunci: \\
Komunikasi \\
Tekstual; \\
Netspeak; \\
Netlingo; Netiket; \\
Halusinasi \\
Konsensual \\
\hline
\end{tabular}

\section{How to cite (APA 7th Edition):}

Choiriyati, W., Fitriani, D. R., \& Susanto, L. (2020). Analysis of Consensual Hallucination Phenomena in Netspeak, Netlingo Practice, and Millennial Generation Netiquette. Al-Balagh: Jurnal Dakwah Dan Komunikasi, 5(1), 117-140. https://doi.org/10.22515/al-balagh.v5i1.2163

\section{INTRODUCTION}

The results of research published by We Are Social in 2020 showed that internet users in Indonesia reached 175.4 million with 64\% penetration. The users of social media in Indonesia based on We Are Social released in 2020 were 160 million with an increase of 12 million compared to the last year ("Digital 2020: Indonesia - DataReportal - Global Digital Insights," 2020). Meanwhile, the release of the research findings conducted by Indonesian Internet Service Management Association/Asosiasi Penyelenggara Jasa Internet Indonesia (APJII) showed that more than 
$90 \%$ of internet users in Indonesia were those who had attended higher education and were aged 15 to 29 years. The results of a survey conducted by the Indonesian Internet Service Management Association revealed that the most significant internet users in Indonesia are predominantly aged 19 to 34 years (APJII, 2018). The age of dominant internet users in Indonesia can be categorized as the millennial generation. Referring to the book published by the Ministry of Women's Empowerment and Children \& the Central Statistics Agency entitled Thematic Gender Statistics: Profile of Indonesian Millennial Generation, the concept of Indonesian millennial generation is the Indonesian population born between 1980 and 2000 (Indah, 2018). The results of other studies reveal that millennials are aged 17 years to 36 years (Al Walidah, 2017).

Results of a study conducted by the Boston Consulting Group in 2011, in (Indah, 2018), states that millennial generation has several characteristics, namely (1) having a higher interest in reading using digital devices compared to conventional reading interest; (2) has social media as a communication tool and information center; and (3) prefer mobile to television. Some experts suggest that the millennial generation is a "click" generation or a "connected" generation.

The parties connected through social media are generally found in the real world. It was answered in research conducted by Utami et al., (2015), which revealed that there had been a shift in communication culture, from regular face-to-face communication to digital media computer communication. Texting culture is called a form of digital communication culture. Millennial generation considered texting culture as a means to build the value of emotional closeness, practicality value in spreading information, and the value of speed and freedom. Following this logic, the textual communication in social media should build emotional closeness between the parties involved, and closeness, which is, of course, more profound than closeness that only merely knows each other. 
The results of research conducted byAyun (2016) found that textual digital communication on social media could not reach the intimate stage. The cause of the inability to grasp the intimacy stage on social media is the inequality of how to perceive textual messages so that it often fails to communicate. Another case showed by Fitria \& Prasetio's (2019) research which was conducted in a virtual community based on factors of imitation, suggestion, and sympathy. These three factors produce various symbols that are interpreted together so that they become the basis for conducting social interaction in the community and forming the image of members. It means that digital communication within the community and individual level has a different degree of cohesiveness. Intimacycan be strengthened by symbolic communication through digital symbols. Refer to research results of Ayun (2016); Existing emoticon facilities serve as a form of expressing feelings to build intimacy at the communication level. This situation then makes the millennial generation believe that textual communication through social media can build intimate closeness for those involved.

Besides the researches mentioned above, there are also other researches about social media, especially on the use of Instagram and Whatsapp. These studies include the phenomenon of obtaining religious knowledge from social media (Mahmuddin \& Halik, 2019), utilize the Instagram for political / campaign purposes (Mohamed, 2019), and utilize social media for public relations work (El-Kasim \& Idid, 2017). Research on social media has also expanded to newer and fresh themes, such as research on Muslim celebrities and their influence on social media (Shariffadeen \& Manaf, 2019), emotion icons interpretation in Whatsapp (Annamalai \& Salam, 2017), and cyberstalking the religious scholars on social media (Syahputra, 2018). In general, the number of these studies show that social media and the digital universe are almost unlimited research fields.

120 Analysis of Consensual Hallucination Phenomena in Netspeak, Netlingo Practice, and Millennial Generation Netiquette Wahyuni Choiriyati, Dinda Rakhma Fitriani, Leo Susanto 
Among the many themes about social media studies, consensual hallucination is rarely on the discussion. Gibson (1984), in the book entitled Neuromancer mentioned the digital world as a consensual hallucination. Consensual hallucination or which, if translated freely in Indonesian, is known as a form of experience that reflects something not real as a reality. The internet, which contains social media in it, is a consensual hallucination. Social media that is part of the web includes the structure built by its users - like in the real world, using social media contains both written and unwritten rules. The structure of the regulations is what then makes each user adjust their communication behavior on social media.

The dynamics of the use of internet languages (internet language), which includes netspeak and netlingo and the existence of internet ethics, make textual communication that occurs in social media interesting to study. A reference for this article is based on the research of Fahrimal (2018), regarding netiquette on social media networks. Fahrimal (2018) stated that there had been a high leap in communication activities through social media, which has created resistance in aspects of social ethics. Millennials, as active users, must realize that the social network system is virtually the same as the social system in real life. Fahrimal (2018) asserts the freedom that exists on the internet, and social media is not without limits. However, the fact is that violations of ethical and moral still occur, such as cyber-bullying, pornography, fraud, online gambling games, even human trafficking.

Anwar (2017) revealed that teenagers and young adults are the most significant users of social media who often express disappointment, sadness, and life problem on social media. Barni (2019), in his article, said that $33 \%$ of Indonesian people are now a millennial generation began to abandon conventional ways of living life, replaced by current trends and lifestyles. It is even more impressive when textual communication on social media reinforces the view that the internet is a form of consensual 
hallucination enhancing by millennials as its users.

Specifically, this article seeks to: 1) describe the forms of digital communication carried out textually on WhatsApp and Instagram by millennials, 2) describe the types of ethos, pathos, and logos that millennial generations build in textual communication on Whatsapp social media and Instagram and 3) show forms of internet affirmation as consensual hallucinations. This phenomenon is reinforced by Mulawarman \& Nurfitri (2017) writing which reviewing the rise of social media user accounts who deliberately display others' photos on their profile or without a profile photo, and a clear identity. The irony of social media user behavior is reflected in reconstructing identity through status or distribution of specific links that try to 'explain' the opposite of themselves to the audience and it does not represent the identity of the user. Furthermore, Sari (2019) confirms that the millennial generation is concerned with personalization and accessories, even if it is only for the sake of aesthetics. Millennials adjust their desires to modify various products as their self-branding.

The findings from this study are expected to provide an overview of how media literacy education can be delivered to millennial generations so that effective communication can occur both in the digital world and in the real world. Literacy stages will generally be productive when it is done collectively, for example, through the distance learning process (distance learning). Etiquette in the process of distance learning is the beginning to synergize ethical and learning issues (Mintu-Wimsat, Lozada, \& Kernek, 2010). Through online learning, students must be introduced to ethics specifically and explained the rules and the consequences in their syllabus. This research expects that literacy culture in the millennial generation can be built more collectively through classroom learning strategies. Literacy culture through online learning approaches is strengthened by the study of Choiriyati et al., (2017), which describes the birth of social competence consists of communicative abilities, including the ability of communication 
and participation through the media. Thus, communicative skills include the ability to build social relations and participate in the community through media, including the use of internet media for social communication processes such as Friendster, Facebook, Twitter, and Myspace and other forms of social media among students.

Character education regarding the basic function of ethics following Law No. 20 of 2003 that national education functions to develop the ability and formation of national character and civilization (Lolo, 2018). Various researches related to the changes in communication ethics become a marker of millennial transformation when responding to this digital era, one of which refers to the analysis of Wartoyo (2019).

Textual communication that occurs on social media related to the language used on the internet or known as the internet language. According to David Crystal in Nasrullah (2014), Internet language is the fourth medium after written language (writing), speaking a language (speaking), and sign language (signing). Internet language contains components such as netspeak, netlingo, and netiquette. Netspeak can be interpreted as a form of oral communication, which is then made in written form. When millennials engage in textual communication on social media, they chat like meeting face-to-face and communicating verbally. Textual communication that occurs on social media is a duplication of chat in the real world so that the text that appears in textual communication on social media represents the language of speech. The reality of shift in communication style and the use of diction described by Fauziyyah (2019), is not because digital natives do not have ethics when they want to convey their messages or opinions from different generations (digital immigrants). Still, the differences in the digital lifestyle affect thought and communication patterns.

Based on Thurlow in Nasrullah (2014), if netspeak is the text that represents the language of speech, netlingo is a form of text in social media as if the text were speaking. In more detail, netlingo is a form 
of communication that relies on texts as if speaking to represent us as communicators. The language used is non-standard language. Social media speech often violates the prerequisites of standard language users. It causes by the time limitation owned by social media users as well as technology device factors such as keyboards and small cell phone sizes.

Typing errors, mistakes in capital letters, and mistakes in punctuation are common in netlingo. It is because there is an assumption that the text is speaking so that grammar is not essential. The existence of netspeak and netlingo might trigger misperceptions in interpreting a text by millennial generation when communicating textually using social media. There are no standard rules on the use of netspeak and netlingo in communicating textually on social media, making each member of the millennial generation develop their own rules. In their research, Thangaraj \& Maniam (2015) write that Netspeak is commonly used among their colleagues when communicating online,which shows the relationships of its members. Netspeak is used as a group identity because each group has the term which is only understood by its members. There is a structure that regulates the procedures that are considered polite in communicating on social media. It is known as netiquette.

According to Thurlow in Nasrullah (2014), Netiquette is ethical and social behavior in using the internet. The existence of netiquette is needed for several things. First, not all social media users come from the same cultural and environmental background, so there is an opportunity for misunderstanding in interpreting messages that are communicated textually on social media. Second, content uploaded on social media does not only go to one party specifically but can be spread indirectly to other parties. Third, although it occurs in the virtual world, textual communication that is carried out on social media is still related to the real world. Fourth, internet ethics (netiquette) is needed so that every user of social media can understand their rights and obligations in communicating and citizens of 
a virtual world (netizens). Further research is conducted by Choiriyati \& Pusat (2019) explained that many of our societies do not have sufficient literacy in understanding communication in cyberspace.

The theory that can be used to read textual communication of millennials social media users is the Theory of Rhetoric from Aristotle. There are two assumptions from the Rhetoric Theory proposed by Aristotle (West \& Turner, 2017). First, effective speakers must consider their audience. In the context of textual communication on social media, ideally, communicators should know who is the interlocutor, so that the message delivered can be valid. Although no written rules are regulating the use of internet language that includes netspeak and netlingo, every communication participant on social media should ideally be able to communicate messages properly to avoid failure in communication.

The second assumption is that effective speakers must present evidence that supports the message it conveys. This second assumption relates to the three components of evidence referred to by Aristotle, namely ethos, logos, and pathos (West \& Turner, 2017). Ethos refers to the character, intelligence, and good intentions of communicators that appear when delivering a message. Logos refers to the logical evidence possessed by the communicator, including the use of reasonable statements, clear language to the rationale behind the expressed statement. Pathos refers to emotions that are involved with the communicant by the communicator, including feelings of pleasure, pain, hate, or fear. This ethos, logos, and pathos components find their form in communication that is done textually on social media. Aristotle's concept of showing his moral philosophy (ethikos) places the word ethics as the science of what is usually done or the science of customs (Afif, 2019).

\section{METHODS}

This research used a qualitative approach. The paradigm used in Analysis of Consensual Hallucination Phenomena in Netspeak, Netlingo Practice, and 
this research is constructivist (Moleong, 2009). Thus, the strategy used in this research is phenomenology (Kusumawati \& Arawindha, 2018). Phenomenology strategies are used to uncover subjective meanings arising from individual textual communication experiences belonging to the millennial generation category using Instagram and Whatsapp social media. Whatsapp and Instagram social media were chosen because both of them became popular social media among millennials. The subjects of this study were six individual Instagram and Whatsapp users, namely YIR, AMR, IDP, TJY, PH, and RW. The research subjects chosen were active users of Instagram and Whatsapp for more than two years. In-depth interviews and observations about Instagram and Whatsapp accounts are used to uncover textual communication experiences through Whatsapp and Instagram social media. Data analysis used interactive data analysis (Miles \& Huberman, 1992). The triangulation used in this research is the triangulation of data sources.

\section{RESULTS AND DISCUSSION}

\section{Internet Language: Netspeak, Netlingo, and Text Modification}

The language used in communicating on social media is different from the language that is generally used in direct communication. In this research, the informant revealed the use of speech-language as a text, such as the expression of surprise for knowing something "oh," which was later modified in writing to "owhhhh ...". It is known as netlingo. Also, there are forms of netspeak. The form of netspeak expressed by the informants in the research is capital letters to express anger. Besides that, many other forms of netspeak that are commonly used. Textual communication used on social media such as Instagram and Whatsapp cannot make a sound. Still, it has become a convention with social media users that the use of capital letters as a whole in a phrase is translated as anger. 
In addition to netspeak and netlingo, social media users such as on Whatsapp and Instagram make text modifications in communicating textually on social media. The first form of text modification is to abbreviate the words used in textual communication. Textual communication on social media such as Whatsapp and Instagram demands urgency from the informants' view. This makes them unable to use the standard language according to the Enhanced Spelling System (EYD). Besides, the habit of sending short messages through the SMS (short message service) feature also makes informants accustomed to communicating by shortening words. Abbreviate words in textual communication on social media are considered as a common norm. On the contrary, writing on length sentences through social media like Whatsapp or Instagram is considered as something strange.

"If I chat on Whatsapp or IG [Instagram], I mostly shortened the term for example "mantul which stands for "mantap betul" (Interview with YIR, 29 June 2019).

The next form of text modification commonly used in textual communication on social media is to combine letters and numbers in word order and text presentations such as bold, italic, or underlined. The use of letters and numbers in composing words is often used in communicating on social media, as expressed by the informants in this study. Writing this combination is used to shorten the time in writing; for example, to express sentences "dua-duanya" usually the textual communication is " $22 n y a$ ". It also becomes a common thing in textual communication on social media. Besides, the form of modifications was made on writing, such as bold, italic, or underline. It was done by the informant on his chat to get more attention. From the informants' perspective, it is more interesting to do than doing a textual communication with standard writing display. 


\section{The ethos of Textual Communication on Social Media:Motivation for Uploading Content on Social Media}

In the Theory of Rhetoric proposed by Aristotle, there is a component of Ethos. Ethos in the perspective of Aristotle's Rhetoric Theory is a former intention for carrying out an activity of rhetoric. In the context of this research, Ethos from Aristotle's Rhetoric Theory is translated as the motive of the millennial generation in uploading content on social media. In this study, it was found four things like the motivation or ethos of the millennial generation in uploading content on social media. The first is expressing the current mood. One informant in this study revealed that the content he posted on social media such as Instagram described his current feeling. It showed that the motivation behind uploading content on social media was a personal motive and related to a person's psychological factors.

Second, the informant's motivation is to represent their identity. It is illustrated by informants who use Instagram to upload photos related to their activities as a person who has hobbies visiting new places (travelers) or even hobbies visiting places with good food (food traveler). Also, the informants in this study revealed that the content uploaded on social media was used to describe himself as a person who likes photography. Related to those motives, content uploaded on their social media is about food, tourism places, and also a pet. It was done to represent their identity to followers on social media.

"I usually post things related to my photography hobby" (Interview with YIR, 29 June 2019). "ON IG [Instagram], I usually post about food or places that I visited during traveling" (Interview with IDP, 01 July 2019).

Third, the motivation of informants who are a millennial generation in uploading content on social media is information sharing. It is usually in the form of writing that explains the photos uploaded on the Instagram 
informant (caption). Another way is the text that is sent in the Whatsapp group account in the form of discussion material or discussion to motivation. Informants revealed that in compiling captions on Instagram, informants tended to use in-depth descriptions. It aims to make this information as a reference for other parties. One example revealed by informants is the preparation of a caption for photos to visit a place in another country. The informant mention that he would describe as clearly as possible about the place. What was to be prepared and what was allowed or forbidden to be done at the location. Uploads in the Whatsapp group are varied, ranging from small talk to motivation to improve.

Fourth, the motivation of informants in uploading content on social media (Instagram) is to capture precious moments in life or make social media accounts like Instagram as a digital diary. The content uploaded by the informant through his personal Instagram account mostly contains photos with the closest people and important events for example graduation moment of the informant's sister. The caption in the uploaded photo usually contains pieces of information about the moment, who is in the photo, and the relationships of people on it. The informant also revealed that he also used quotes from figures that reflected the images he uploaded on his personal Instagram account.

\section{Digital Textual Communication Logos: Review before Uploading}

In the Theory of Rhetoric proposed by Aristotle, there is a concept called logos. The idea of logos can be explained as the rationale behind the use of rhetoric. In this study, the idea of logos is translated as the rationalization behind the reason for uploading on social media. At present, the concept of logos proposed by Aristotle's Rhetoric Theory finds its urgency due to the widespread of information or false news (hoaxes). The concept of logos is related to personal credibility related to content uploaded on social media. Two forms of logos were found in 
this study. The first is the use of sentences that are as effective as possible to suppress multiple interpretations (multi-interpretation) of uploaded content. Textual communication on social media is interpreted differently from each other by participants. The number of individuals who read content uploaded on social media may create various meanings according to the individual frame of reference and field of experience. To suppress this, the informant revealed that he tends to be selective in using diction, using capital letters to punctuation. Mistakes in the use of these things can lead to conflicts that result in destructive.

"I prefer to choose diction, punctuation, and capital letters when communicating textually on WA (Whatsapp) and IG (Instagram) because people can misinterpret and influence our relationships" (Interview with YIR, 29 June 2019).

The second form of Logos in this research is to examine the information and sources before spreading information on social media. The rise of the spread of information or false news (hoaxes) because individuals prioritize speed rather than accuracy. There is an English term "think before you speak". This term was later adapted in the context of information development in the current era of social media to "think before you spread". Finger speed that overcomes the speed of logic and individual rationality in reasoning information is considered to be one of the critical factors on news spreading. The informants in this study tend to learn the information in detail before spreading the information. The informant also included information sources, usually in the form of links.

"The information that we post (on social media), the source must be traceable, and clear" (Interview with YIR, 29 Juni 2019). 


\section{Pathos Digital Textual Communication: Using Emoticons, Images, and Quotes}

The concept of pathos in Aristotle's Theory of Rhetoric describes the emotions involved in communicating by the communicator in his rhetorical activities. These emotions can be sad, happy, or angry. In the context of this research, the concept of Pathos is translated as emotional forms involved in textual communication on Instagram and Whatsapp social media. Emotional forms in textual communication on social media were divided into three, namely emoticons, images, and quotes. The word emoticon itself is an acronym of emotions and icons. Emoticons are visualized in the form of facial animations in various emotional expressions. Emoticons are used to describe feelings when communicating textually on social media. Written sentences expressed on social media cannot explicitly define the emotions of the author, so an emoticon is needed to describe the feelings of the author. The informant in this study uses emoticons to ensure the message he conveys is delivered and interpreted as it is. It is also to ensure that the communicant does not interpret forms of textual communication contrary to what is expected. It is essential to be done by informants when communicating with superiors in the office, parents, and colleagues.

"If I want to express feelings on my Instagram or WA (Whatsapp), I usually use emoticons or images and varied emoticons that can be used" (Interview with YIR, 29 June 2019).

In addition to emoticons, the emotional form involved in textual communication on social media is the use of both static and dynamic images (GIF). Emoticons have indeed become the dominant form used in expressing emotions when communicating textually on social media. However, the informant said that emoticons cannot always show their emotional state when communicating textually on social media as a whole. Other forms, such as GIF images, people laugh out loud, or someone's 
facial expressions in GIF images are considered by informants to be more representative in expressing their feelings. In addition to GIF images, static images are also the choice of informants in expressing their feelings. One informant revealed that he used a static image of a busy party to express happiness. The use of GIF images and static images is subjective, depending on each individual.

A form of emotional expression when communicating textually on social media besides using emoticons and pictures is to use quotes. Informants in this study revealed that other than images or emoticons, another form used in expressing emotions is to use quotes of wise sentences. It is generally used on Instagram in the form of captions to complete photos uploaded on Instagram accounts. Not infrequently, the informant revealed that he only uploaded quotes that expressed his mood.

"I use quotes when I want to express my feelings when communicating on social media like Instagram" (Interview AMR, 29 June 2019).

\section{The Urgency of Netiquette in Digital Textual Communication on Social Media}

Textual messages exchanged in textual communication on social media are often interpreted differently by other parties. Also, some parties upload content on social media only to bully other parties, which are considered more inferior than themselves. Various social media platforms such as Instagram, Facebook, Twitter to Whatsapp are platforms that can be accessed by the public. It indicates that not only one individual can receive messages sent on social media, but many people can receive these messages. Most individuals who lack understanding about social media ethics assume that their social media accounts belong to them just like physical goods they buy. So, they are free to do anything on social media, including insulting, bullying, and harassing others. 
"For millennials, there is an assumption that their social media is theirs (personal belongings). So, they think they are free to do anything through social media" (Interview with TL, 26 June 2019).

The ethics of communication on social media finds its urgency when many parties use social media to express themselves excessively when they feel that the real world is too restraining itself. Some individuals use social media to show rebellion against some things in the real world that disturb them. These individuals find it challenging to express dislike or rejection of things that disturb him in the real world. In other conditions, individuals like this see things happening in the real world differently from what he considers to be a truth. Still, these individuals find it difficult to express their views. Many things that might be a hindrance, could be because he was an inferior person, felt nobody, and got pressure from other parties. Individuals like this use social media as a means to express their sense of rebellion against things that in contrast to him. It is because there is an assumption that social media is a medium that guarantees anonymity so that others will not know their identity in the real world.

"There are also people who use social media to do things that he can't do in the real world because his true identity will not be discovered." (Interview with AMR, 29 June 2019).

The ethics of communication on social media find its urgency because of the large number of internet users in Indonesia and its insufficient knowledge about effective social media ways. Many internet users use social media according to their wishes regardless of the other party. Many social media users do not have a sufficient level of social media literacy. It can be seen from a large number of non-constructive content uploaded on social media. Upload content that does not consider ethical principles. For example, using abusive words to express their anger in the real world in the form of the caption on social media. It is still often found on social media. Also, many users prefer to "spread first and then 
read" instead of "read first then spread". It raises viral things on social media and searches it until the real world even though it often just trivial things. At this point, communication ethics education on social media finds its urgency.

\section{Consensual Hallucinations for Millennial Generation of Social Media Users}

Consensual hallucinations can be understood as an experience in cyberspace that is considered as real. The internet is considered as the real world because of the structures that govern life on the internet. Social media, which is part of the internet, is one aspect that strengthens the internet as a form of consensual hallucinations. More specifically, this study reveals micro things that reinforce the view that social media is a form of consensual hallucinations.

First, the millennial generation, as social media users consider social media as their personal property. It is because everything related to social media accounts is constructed by himself so that there is an impression that it belongs to him like a physical item he buys in the real world. Indeed, owned social media accounts can be taken over by the social media platform provider. It is done usually due to reports of legal violations or the provider platform close it permanently. At this point, social media users have no power at all. Social media users can use social media as long as the owner of the social media platform allows it.

The second thing that supports the view that the internet and social media are forms of consensual hallucinations is the assumption that social media is a free and equal place so that there are no restrictions like the real world. It can be understood because there is an assumption that when communicating on social media, everyone is in an equal position. Everyone can communicate with each other without being separated by social stratification boundaries. A student can communicate with the 
president via social media platforms. Ideally, this condition is painful to occur in the real world. But does this indicate that all are equal? There are several things to watch showing that not all things are equal on social media.

First, some parties have more power in social media, such as social media platform owners and social media regulators. The owner can close all social media accounts when he wants to. Social media regulators such as the government may block access to social media if they are harmful. One thing that is special in Indonesia is the use of "rubber law" in the ITE, particularly Article 27 regarding defamation. It can be used by persons to tackle critics on social media. So, considering social media is the same as real world is a hallucination.

The third thing is that social media guarantees anonymity so that everything that is done on social media is "safe". It can be seen from the use of social media account names that combine letters and numbers, which in the language of the millennial generation is known as Alay. Even if they don't use Alay words, social media users use an identity that does not belong to them-for example, using an anonymous and avatar. Social media provides flexibility so that there is an assumption that everything on social media is safe because it is difficult to trace the user. It was later denied by the number of hoax spreader accounts that did not use real identities such as Saracen, who were eventually arrested by the police. This condition is traced using internet protocol addresses and other content uploaded on social media. Everything will have a digital trace that can be tracked. So saying that social media is safe because it can use anonymous identity is not true and is a form of hallucination.

The fourth thing is that textual communication that occurs on social media will have the same level of effectiveness as in the real world. It can be understood when social media provides various tools that support the transformation of physical expressions into the verbal language in 
an equivalent meaning through emoticons. But the fact is that textual communication on social media is prone to be interpreted differently by communication partners. The use of sentences that are often abbreviated or use informal languages, known as netspeak and netlingo, has the potential to cause different interpretations and conflicts. There is also an assumption that mutual relations can be formed through social media; it serves in the real world. The findings in this study precisely revealed that social media is only to strengthen relationships that have been built in the real world. It then shows that textual communication made on social media cannot be equivalent to communication built in the real world. Considering communication textually on social media similar to the real world is a consensual hallucination.

\section{CONCLUSION AND SUGGESTION}

\section{Conclusion}

Textual communication on social media carried out by the millennial generation contains ethos, pathos, and logos. The philosophy of textual communication in social media is to express the feeling that is being experienced, to represent one's identity, and share information. The logos form of textual communication on social media is the use of sentences that are as effective as possible to avoid multiple interpretations of uploaded content and examine the information and sources of information before spreading the news on social media. The pathos of textual communication on social media is the use of emoticons, images, and quotes to express feelings textually.

In communicating textually on social media, the millennial generation uses netspeak, netlingo, and text modification. The netspeak form used is the use of capital letters to express anger. The type of netlingo used is an expression of being surprised to know something. The modified form of text used is to combine letters and numbers in word preparation and 
presentation of text such as bold, italic, or underlined. Communication ethics is known as netiquette, which is understood by the millennial generation.

Social media, which is part of the internet, affirms the notion that the internet is a consensual hallucination. It is because the consensual forms of hallucinations are found in the millennial generation of social media users. Those forms of consensual hallucinations are shown on how they generation perceive social media as their personal property, full of freedom and equal place so that there are no boundaries like in the real world, social media guarantees anonymity so that everything is done on social media "safe" so that textual communication on social media will be as effective as that in the real world.

\section{Suggestion}

Based on the findings of this study, concrete action is needed in the form of building media literacy education in the primary to higher education curriculum in Indonesia. It is crucial to improve the quality of media literacy among the community, especially the younger generation so that they can use the media appropriately. As for future research, other methods such as virtual ethnography can be used to get a more in-depth picture of the phenomenon of consensual hallucinations.

\section{REFERENCES}

Afif, M. B. (2019). Konsep Etika Epikuros dan Problem Media Sosial. Indonesian Journal of Islamic Theology and Philosophy, 1(2), 1-22. https://doi.org/10.24042/ijitp.v1i2.5029

Al Walidah, I. (2017). Tabayyun di Era Generasi Milenial. Jurnal Living Hadis, 2(2), 317-344. https://doi.org/10.14421/livinghadis.2017.1359. 
Annamalai, S., \& Salam, S. N. A. (2017). Undergraduates' Interpretation on Whatsapp Smiley Emoji. Jurnal Komunikasi: Malaysian Journal of Communication, 33(4), 89-103. https://doi.org/10.17576/ JKMJC-2017-3304-06

Anwar, F. (2017). Perubahan dan Permasalahan Media Sosial. Jurnal Muara Ilmu Sosial, Humaniora, Dan Seni, 1(1), 137-144. https:// doi. org/10.24912/jmishumsen.v1i1.343

APJII. (2018). Penetrasi \& Profil Perilaku Pengguna Internet Indonesia: Survey 2018. In apjii.or.id. Retrieved from https://apjii.or.id/ survei2018s/download/TK5oJYBSyd8iqHA2eCh4FsGELm3ubj

Ayun, P. Q. (2016). Penggunaan Instant Messanger dan Komunikasi Interpersonal Remaja. Jurnal Ilmu Sosial, 15(2), 111-120. https:// doi.org/10.14710/jis.15.2.2016.111-120

Barni, M. (2019). Tantangan Pendidik Di Era Millenial. Transformatif, 3(1), 99-116. https://doi.org/10.23971/tf.v3i1.1251

Choiriyati, W., \& Pusat, A. W. (2019). Etika Media Dalam Kultur New Technology (Mengkaji Etika Internet Versus Undang Undang Informasi dan Transaksi Elektronik). Jurnal Masyarakat \& Budaya, 21, 247-261. https://doi.org/10.14203/JMB.V21I2.763

Choiriyati, W., Rufaidah, V. W., \& Turistiati, A. T. (2017). Literasi Media Siswa Dalam Penggunaan Internet Di Sekolah Alam Bogor. Lugas Jurnal Komunikasi, 1(2), 108-118. https://doi.org/10.31334/ljk. v1i2.440

Digital 2020: Indonesia - DataReportal - Global Digital Insights. (2020). Retrieved February 19, 2020, from datareportal.com website: https://datareportal.com/reports/digital-2020-indonesia.

El-Kasim, M., \& Idid, S. A. (2017). PR Practitioners' Use of Social Media: Validation of an Online Relationship Management Model Applying Structural Equation Modeling. Jurnal Komunikasi: Malaysian Journal of Communication, 33(1), 212-228. https://doi.org/10.17576/ jkmjc-2017-3301-15

Fahrimal, Y. (2018). Netiquette: Etika Jejaring Sosial Generasi Millenial Dalam Media Sosial. Jurnal Penelitian Pers Dan Komunikasi Pembangunan, 22(1), 69-78. https://doi.org/10.46426/jp2kp. v22i1.82 
Fauziyyah, N. (2019). Communication Ethics Of Digital Natives Students Through Online Communication Media To Educators: Education Perspective. Jurnal Pedagogik, 06(02), 437-474.

Fitria, A. M., \& Prasetio, A. (2019). Konstruksi Citra Anggota Komunitas Virtual pada Bigo Live. PRofesi Humas Jurnal Ilmiah Ilmu Hubungan Masyarakat, 3(2), 141-158. https://doi.org/10.24198/prh. v3i2.12918

Gibson, W. (1984). Neuromancer. New York, United States: Ace Books.

Indah, B. (2018). Statistik Gender Terapan: Profil Generasi Milenial. Jakarta: Kementerian Pemberdayaan Perempuan dan Perlindungan Anak bekerjasama dengan Badan Pusat Statistike.

Kusumawati, \& Arawindha. (2018). Fenomenologi. In Kholifah dan Suyadnya (Eds), Metodologi Penelitian Kualitatif Berbagi Pengalaman dari Lapangan. Jakarta: Rajagrafindo Persada. Depok: Rajagrafindo Persada.

Lolo, K. (2018). Menciptakan Generasi Milenial Berkarakter Dengan Pendidikan Karakter Guna Menyongsong Era Globalisasi. Jurnal Ilmu Kepolisian, 12(2), 68-75.

Mahmuddin, \& Halik, A. (2019). The Use of Social Media as a Source of Religious Knowledge among Doctors in Makassar, Indonesia. Jurnal Komunikasi: Malaysian Journal of Communication, 35(4), 272285. https://doi.org/10.17576/JKMJC-2019-3504-17

Miles, \& Huberman. (1992). Analisis Data Kualitatif. Jakarta: Universitas Indonesia.

Mintu-Wimsat, A., Lozada, H. R., \& Kernek, C. (2010). Netiquette: Make it Part of Your Syllabus. MERLOT Journal of Online Learning and Teaching, 6(1).

Mohamed, S. (2019). Instagram and Political Storytelling among Malaysian Politicians during the 14th General Election. Jurnal Komunikasi: Malaysian Journal of Communication, 35(3), 353-371. https://doi. org/10.17576/JKMJC-2019-3503-21

Moleong, L. J. (2009). Metode Penelitian Kualitatif. Bandung: Remaja Rosdakarya.

Mulawarman, M., \& Nurfitri, A. D. (2017). Perilaku Pengguna Media Sosial beserta Implikasinya Ditinjau dari Perspektif Psikologi Sosial Terapan. Buletin Psikologi, 25(1), 36-44. https://doi.org/10.22146/ 
buletinpsikologi.22759

Nasrullah, R. (2014). Teori Dan Riset Media Siber (Cybermedia). Jakarta: Kencana Prenadamedia Group.

Sari, S. (2019). Literasi Media Pada Generasi Millenial Di Era Digital. Professional: Jurnal Komunikasi dan Administrasi Publik, 6(2), 30-42. https://doi.org/10.37676/professional.v6i2.943.

Shariffadeen, T. S. A. T. M. A., \& Manaf, A. M. A. (2019). Celebrity-fan Engagement on Instagram and its Influence on the Perception of Hijab Culture among Muslim Women in Malaysia. Jurnal Komunikasi: Malaysian Journal of Communication, 35(1), 286-302. https:/ / doi.org/10.17576/JKMJC-2019-3501-19

Syahputra, I. (2018). New Media, New Relations: Cyberstalking on Social Media in the Interaction of Muslim Scholars and the Public in West Sumatra, Indonesia. Jurnal Komunikasi: Malaysian Journal of Communication, 34(1), 153-169. https://doi.org/10.17576/ JKMJC-2018-3401-09

Thangaraj, S. R., \& Maniam, M. (2015). The Influence of Netspeak on Students' Writing. Journal of Education and Learning (EduLearn), 9(1), 45-52. https://doi.org/10.11591/edulearn.v9i1.963

Utami, A., Lestari, M., \& Putra, A. (2015). Pergeseran Budaya Komunikasi Pada Era Media Baru (Studi Etnografi Virtual Penggunaan LINE oleh Digital Natives). E Proceeding Of Management, 2(3), 4042-4050.

Wartoyo, F. X. (2019). Etika Komunikasi Mahasiswa dan Dosen Dalam Perspektif Akademis Revolusi 4.0. WASKITA: Jurnal Pendidikan Nilai Dan Pembangunan Karakter, 3(1), 39-47. https://doi. org/10.21776/ub.waskita.2019.003.01.4

West, R., \& Turner, H. L. (2017). Pengantar Teori Komunikasi. Jakarta: Salemba Humanika. 